\title{
Canine Parvovirus Infection, Canine Distemper and Infectious Canine Hepatitis: Inclination to vaccinate and Antibody Response in the Swedish Dog Population
}

\author{
By P. Olson ${ }^{1}$, A. Hedhammar', and B. Klingeborn ${ }^{2}$ \\ ${ }^{1}$ Department of Medicıne and Surgery, Faculty of Veterinary Medicine, Swedish University of Agricultural Sci- \\ ences, Uppsala, and ${ }^{2}$ Department of Virology, The National Veterinary Institute, Uppsala, Sweden.
}

\begin{abstract}
Olson, P., Å. Hedhammar and B. Klingeborn: Canine parvovirus infection, canine distemper and infectious canine hepatitis: Inclination to vaccinate and antibody response in the Swedish dog population. Acta vet. scand. 1996, 37, 433-444. - The inclination of dog owners to vaccinate was investigated by sending a questionnaire to randomly selected Swedısh dog-owning households. According to the owners $(n=538)$, $86.7 \%$ of the dogs had been vaccinated against CPV and $95.8 \%$ had been vaccinated against $\mathrm{CD} / \mathrm{ICH}$. The inclination to vaccinate mixed breeds was significantly lower than the inclination to vaccinate pure-bred dogs. In a second study titres of CPV, CD and CAV-1 virus antibodies were measured in 176 randomly selected dogs with known vaccination histories. CPV antibody titres $\geq 1: 80$ were detected in $70.9 \%$ of the CPV vaccinated dogs. There was a significant difference in the fraction of dogs with CPV titre $\geq 1.80$ between the group last vaccinated with live attenuated vaccine and the group last vaccinated with inactivated vaccine. Titres of $C D$ and $C A V-1$ virus antibodies $\geq 1: 16$ were found in $86.1 \%$ and $91.6 \%$ of the vaccinated dogs respectively. The fraction of dogs with CAV-1 antibody titres $\geq 1: 16$ was significantly greater in the group that received inactivated CAV-1 vaccine than in the group vaccinated with attenuated live CAV-2 vaccine. Approximately $50 \%$ of the dogs were booster vaccinated against all 3 diseases at one year of age.
\end{abstract}

adeno virus; vaccination.

\section{Introduction}

In Sweden dogs are regularly vaccinated against canine parvovirus (CPV) infection, canine distemper $(\mathrm{CD})$ virus infection and canine adenovirus-1 (CAV-1) infection. CAV-1 being the cause of infectious canine hepatitis (ICH). The vaccines used against CPV infection are either live attenuated or killed. It is standard practice to vaccinate puppies against CPV at 7-8, 12,16 and 20 weeks of age if using a killed vaccine, and at 7-8 and 12 weeks of age if using an attenuated live vaccine. In both cases a revaccination is recommended at 1 year of age
(Olson et al. 1987, Olson et al. 1988, Wierup et al. 1982). Boosters can then be given annually or every other year.

To protect against $\mathrm{CD}$ and $\mathrm{ICH}$ pups are either given 2 vaccinations at 7 and 12 weeks of age, or one vaccination at 12 weeks of age. A re-vaccination at 1 year of age is also recommended (Olson et al. 1987, Olson et al. 1988). Re-vaccinations of adult dogs are most commonly performed either every second year or every 4th year thereafter. All vaccines used in Sweden against $\mathrm{CD}$ and $\mathrm{ICH}$ are attenuated live canine distemper virus (CDV) vaccines combined with 
the vaccine against $\mathrm{ICH}$. The latter component consists of either inactivated CAV-1 or modified live canine adenovirus-2 (CAV-2), the strain which causes respiratory disease in dogs. This study was undertaken to investigate the inclination to vaccinate dogs against CPV infections, $\mathrm{CD}$ and ICH among Swedish dog owners. We also related antibody titers against CPV, CDV and CAV-1 to the vaccination history in a selected group of dogs.

\section{Materials and methods}

The study consists of 2 parts. The first part (A) is a questionnaire in which dog owners are asked about their inclination to vaccinate. The second part (B) is an antibody titre study of dogs with known vaccination histories.

\section{Questionnaire (part A)}

Dog owners were recruited by telephone from a random sample of all Swedish households. Questionnaires were sent out to 700 dog-owning households, 538 (76.9\%) of which were filled in and returned. The recruiting and sending out/receiving procedures were handled by a professional survey institute together with questions from a commercial dog food company. The owners were asked if and when their dogs had been vaccinated against CPV infection or $\mathrm{CD} / \mathrm{ICH}$, respectively; the choices being within the last year, within the last 2 years, more than 2 years earlier or never. Other information obtained was if the dog was pure-bred or mixed and the age of the dog.

\section{Antibody study (part B)}

Dogs from 6 breeds, i.e. Clumber spaniel, Finnish hound, Italian greyhound, Pointer, Tibetan terrier and West Highland white terrier, were originally selected from the stud book at the Swedish Kennel Club for a study of the genetic relationship between individuals using a DNAfingerprint technique. The individual dogs from these breeds were randomly selected from all dogs born between 1 January 1990 and December 31st 1990, except for the Clumber spaniel and Italian greyhound that were sampled from dogs born between 1 January 1988 and December 31 st 1990 owing to a low number of individuals of these 2 breeds.

The owners were asked to participate by visiting a veterinary clinic, and a blood sample was taken from each dog and plasma was stored in $-20^{\circ} \mathrm{C}$ until analysed. Samples were obtained from 176 dogs. As collection of plasma was performed as a part of another study, the age of the dogs varies. The number of dogs in the different breeds and their age when sampled are presented in Table 1. The dogs' complete vaccination histories were obtained.

There was an equal sex ratio, with $49.4 \%$ male dogs and $50.6 \%$ females. Twenty-three dogs (13.1\%) were younger than one year of age, and 153 dogs were older than one year of age. The mean age of the young dogs was 289 days, range 179-62 days, and the mean age of adult dogs was 721 days (1 year 11 months), range 365-569 days .

Antibodies to CPV were measured by ELISA in plasma and were then assigned haemagglutination-inhibition (HI) test values as previously described (Rimmelzwaan et al. 1990). Virus neutralisation test for detection of antibodies to CDV and CAV-1 were measured as described (Appel \& Robson 1973).

Geometric mean titers (GMT) were calculated. Titers against $\mathrm{CPV} \geq 1: 5120$ were designated as $1: 5120$, and titers against CDV and CAV-1 $\geq 1: 256$ were designated as 1:256.

Statistical analyses were performed using the JMP statistical software from SAS Institute Inc. 1989-1994. Comparison between proportions of dogs was performed by using chi-square or Fischer's exact test, and comparison between 
Table 1. Numbers and ages of dogs of different breeds included in the antibody study.

\begin{tabular}{lccccc}
\hline Breed & No. of dogs & $\%$ & $\begin{array}{c}\text { Mean age } \\
\text { Days }\end{array}$ & $\begin{array}{c}\text { Min age } \\
\text { Days }\end{array}$ & $\begin{array}{c}\text { Max age } \\
\text { Days }\end{array}$ \\
\hline Clumber spaniel & 32 & 18.2 & 978 & 302 & 1569 \\
Finnish hound & 27 & 15.3 & 703 & 371 & 915 \\
Italian greyhound & 25 & 14.2 & 698 & 225 & 1282 \\
Pointer & 33 & 18.8 & 574 & 262 & 980 \\
Tibetan terrier white & 29 & 16.5 & 515 & 188 & 809 \\
West Highland terrier & 30 & 17.0 & 526 & 179 & 904 \\
Total & 176 & 100 & 667 & 179 & 1569 \\
\hline
\end{tabular}

Table 2. Dog owners' response to questionnaire (study A) on vaccination against CPV enteritis, CD and ICH.

\begin{tabular}{|c|c|c|c|c|}
\hline \multirow{2}{*}{ Vaccinated latest } & \multicolumn{2}{|c|}{ CPV enteritis } & \multicolumn{2}{|c|}{$\mathrm{CD}$ and $\mathrm{ICH}$} \\
\hline & No. & $\%$ & No. & $\%$ \\
\hline Within 1 year & 248 & 47.3 & 229 & 43.9 \\
\hline Withın 2 years & 81 & 15.5 & 105 & 20.1 \\
\hline$>2$ years ago & 125 & 23.9 & 166 & 31.8 \\
\hline Never & 44 & 8.3 & 15 & 2.9 \\
\hline Do not know & 26 & 5.0 & 7 & 1.3 \\
\hline Total & 524 & 100 & 522 & 100 \\
\hline
\end{tabular}

levels of titres was performed by using Student's T-test.

\section{Results}

Questionnaire (part A)

In total, answers were obtained from 524 owners regarding CPV vaccination and 522 regarding $\mathrm{CD} / \mathrm{ICH}$ vaccination. The results of the questionnaire are presented in Table 2. According to the owners, $86.7 \%$ of the dogs had been vaccinated at some time against $\mathrm{CPV}, 62.8 \%$ within the last 2 years. The percentage of dogs that, to the knowledge of their owners, had never been vaccinated against $\mathrm{CPV}$ infection was $8.3 \%$. The CPV vaccination status of the dogs in relation to their age were obtained from 479 owners and are presented in Fig. 1. In dogs younger than 6 months of age all but one had been vaccinated against $\mathrm{CPV}$; the owner of the remaining dog did not know its vaccination history. Out of all dogs less than 12 months of age, $88.3 \%$ had been vaccinated at least once against CPV. Out of dogs older than one year of age, $4.6 \%$ of the owners stated that their dogs had never been vaccinated against CPV, and 5.9\% of the owners did not know their dogs' vaccination status.

A $95.8 \%$ proportion of the dogs had been vaccinated at some time against $\mathrm{CD} / \mathrm{ICH}$, with $64.0 \%$ vaccinated within the last 2 years. Only $2.9 \%$ of the dog owners responded that, to their knowledge, their dogs had never been vaccinated against $\mathrm{CD}$ and $\mathrm{ICH}$. The relation between $\mathrm{CD} / \mathrm{ICH}$ vaccination status and age for 488 dogs is presented in Fig. 2. In dogs younger than 6 months of age $70.6 \%$ had been vaccinated against $\mathrm{CD} / \mathrm{ICH}$. Out of all dogs less than 12 months of age, $80.5 \%$ had been vaccinated 


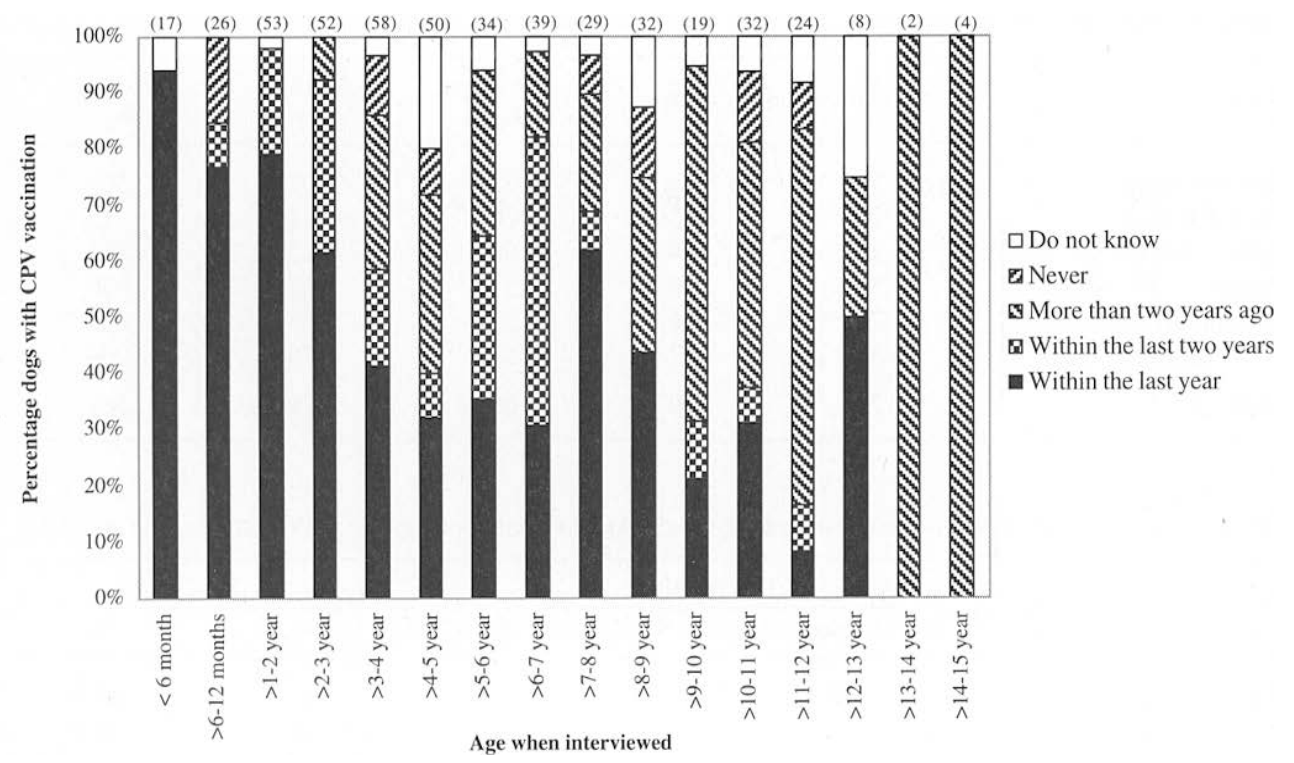

Figure 1. Percentage of dogs in various age classes that were vaccinated against CPV enteritis at different ages. Number of dogs in each age group in paranthesis.

at least once against $\mathrm{CD} / \mathrm{ICH}$. Out of dogs older than one year of age only $1.2 \%$ of the owners stated that their dogs had never been vaccinated against $\mathrm{CD} / \mathrm{ICH}$, and $3.7 \%$ of the owners did not know their dogs' vaccination status.

The proportions of dogs vaccinated at least once against $\mathrm{CPV}$ and $\mathrm{CD} / \mathrm{ICH}$ were higher for pure-breds than for mixed. The percentage of dogs vaccinated against CPV infection was $89.9 \%$ in purebreds and $69.8 \%$ in mixed breeds $(\mathrm{p}<0.001)$. Corresponding figures for vaccination against $\mathrm{CD} / \mathrm{ICH}$ are $97.6 \%$ in purebreds and $85.4 \%(p<0.001)$ in mixed breeds.

\section{Antibody study (part B)}

Vaccination against CPV had been performed in 165 dogs, of which it was possible to determine the type of vaccine for 157 . Twenty dogs had been vaccinated with live attenuated CPV vaccine and 137 dogs with killed CPV vaccine as the most recent vaccine. Vaccinations against
$\mathrm{CD} / \mathrm{ICH}$ had been performed in 166 dogs. The type of ICH vaccine could be determined in 159 dogs of which 34 were vaccinated with killed CAV-1 vaccine and 125 dogs with live attenuated $\mathrm{CAV}-2$ vaccine.

Prior to 6 months of age $93.3 \%$ of all dogs had been vaccinated at least once against $\mathrm{CPV}$, and $97.6 \%$ had been vaccinated at least once before 12 months of age. Corresponding figures for $\mathrm{CD} / \mathrm{ICH}$ was $88.5 \%$ vaccinated prior to 6 months of age and $95.2 \%$ before 12 months of age. Of the dogs vaccinated before 12 months of age, $51.4 \%$ were booster vaccinated against CPV and $53.9 \%$ against $\mathrm{CD} / \mathrm{ICH}$ between 1 and 2 years of age. On average, the dogs had been vaccinated 3.2 times (median 3 times) against $\mathrm{CPV}$, and 1.5 times (median 2 times) against $\mathrm{CD} / \mathrm{ICH}$. The mean time for all dogs since the most recent vaccination against CPV was 315.7 days (median value of 277.0 days). The mean time for all dogs since the previous vaccination 


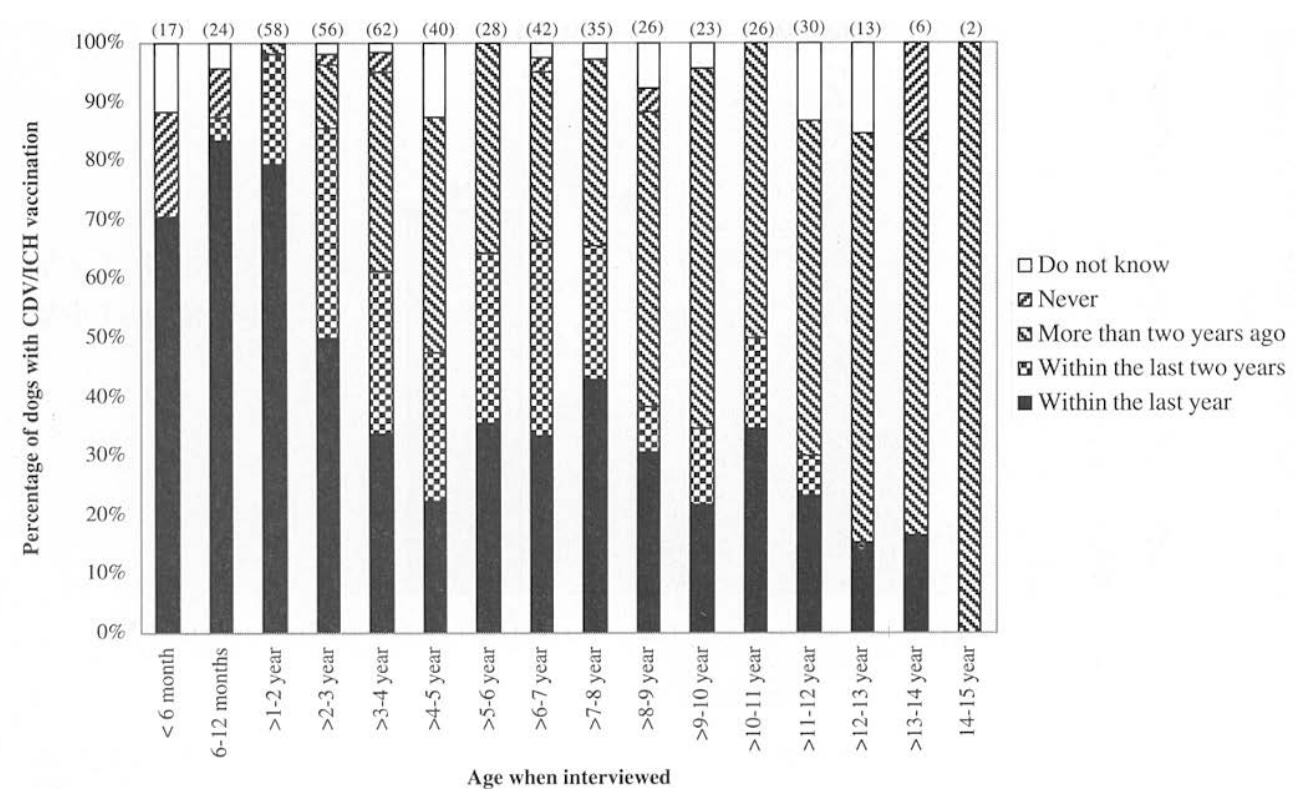

Figure 2. Percentage of dogs in various age classes that were vaccinated against $\mathrm{CD} / \mathrm{ICH}$ at different ages. Number of dogs in each age group in paranthesis.

against $\mathrm{CD} / \mathrm{ICH}$ was 355.3 days (median value of 309.5 days).

Breed differences were found in the age at which the first vaccination was performed. In dogs vaccinated before one year of age, the Finnish hound was on average vaccinated against CPV at 139 days of age, whereas the mean for all other breeds was 67 days, corresponding figures for $\mathrm{CD} / \mathrm{ICH}$ was 151 days and 96 days respectively. These differences being statistically significant. There was also significant breed-related variation in the time since the most recent vaccinations, being longer for Clumber spaniels and Finnish hounds compared with some of the other breeds (Table 3).

Among the dogs known to have been vaccinated against CPV, $70.9 \%$ had CPV titre $\geq 1: 80$. Out of 11 dogs without a documented CPV vaccination only 2 had antibody titers $\geq 1: 80$ $(18.2 \%)$. The differences in the proportion of vaccinated and non-vaccinated dogs with $\mathrm{CPV}$ titre $\geq 1: 80$ was significant $(p<0.001)$. Among the dogs documented to have been vaccinated against $\mathrm{CD}, 86.1 \%$ had a $\mathrm{CD}$ virus antibody titres $\geq 1: 16$. Of the $10 \mathrm{dogs}$ not documented as having been CD vaccinated seven (70\%) had antibody titers $\geq 1: 16$. For the dogs documented to have been vaccinated against $\mathrm{ICH}, 91.6 \%$ had ICH virus antibody levels $\geq 1: 16$. Of the 10 dogs without a documented ICH vaccination eighth (80\%) had ICH virus antibody titers $\geq 1: 16$. The differences in the percentage of vaccinated and non-vaccinated dogs with $\mathrm{CD} / \mathrm{ICH}$ virus titre $\geq 1: 16$ was not significant.

Among the dogs last vaccinated with attenuated CPV vaccine the proportion reaching $\geq 1: 80$ was $90.0 \%$ as compared with $68.6 \%$ among dogs last vaccinated with killed vaccine. This difference was statistically significant $(\mathrm{p}<0.05)$ (Fig. 3). 


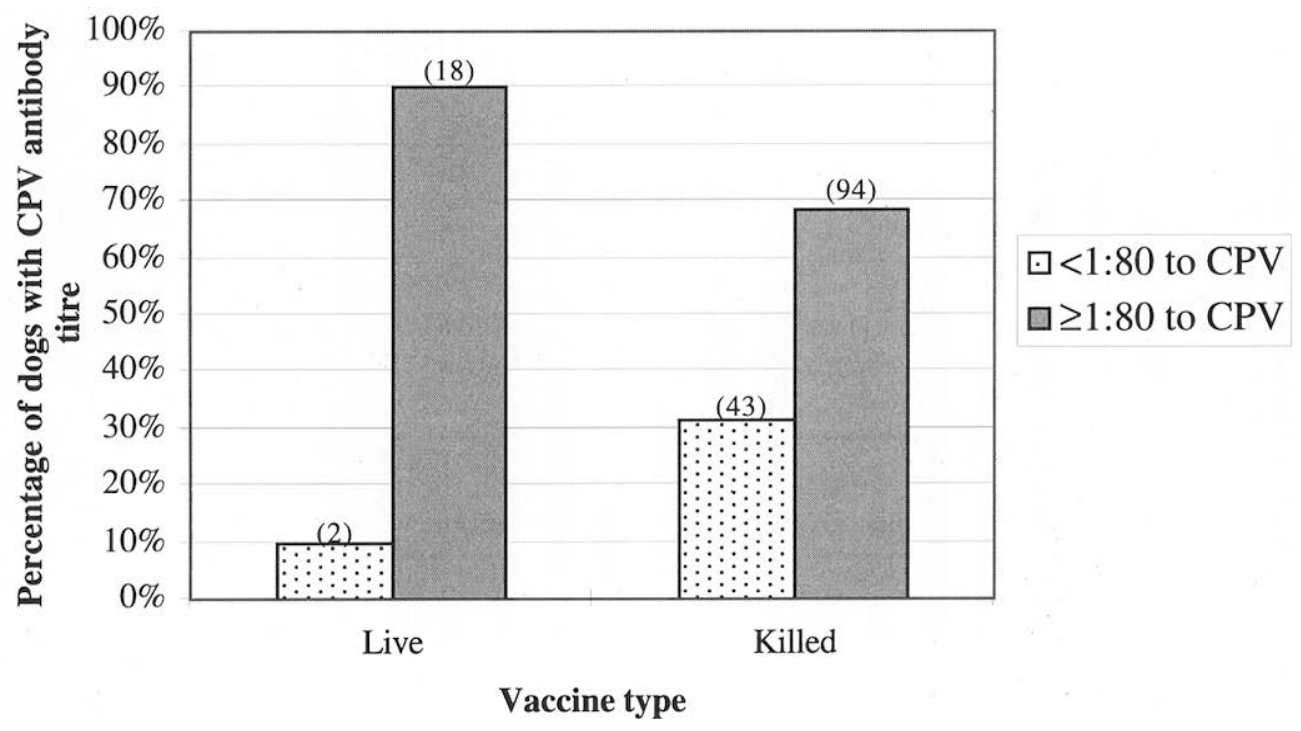

Figure 3. Percentage of dogs with CPV antibody titres $\geq 1: 80$ in groups vaccinated with live and killed vaccines.

Among the dogs that received the attenuated CAV-2 vaccine the percentage reaching $\geq 1: 16$ was $89.6 \%$. The corresponding value for the group receiving the killed CAV-1 vaccine was $100 \%$. This difference is statistically significant $(\mathrm{p}<0.05)$ (Fig. 4).

The overall GMT against CPV in vaccinated dogs was 1:99. It was 1:90 in dogs last vaccinated with killed vaccines and 1:187 in dogs last vaccinated with attenuated vaccines. This difference was not statistically significant. The overall GMT to $\mathrm{CD}$ virus in vaccinated dogs was 1:60. The overall GMT to CAV-1 in vaccinated dogs was $1: 84$. There was a statistically significant difference $(p<0.05)$ in GMT to CAV1 between dogs vaccinated with killed CAV-1 at $1: 126$ and those receiving attenuated CAV-2 vaccine at 1:75.

There was no significant difference in the proportion of dogs with CPV antibody levels $\geq 1: 80$

Table 3. Mean time (days) since the last $\mathrm{CPV}$ and $\mathrm{CD} / \mathrm{ICH}$ vaccination.

\begin{tabular}{lll}
\hline Breed & $\begin{array}{l}\text { Mean time since last CPV } \\
\text { vaccination (days) }\end{array}$ & $\begin{array}{l}\text { Mean time since last } \\
\text { CD/ICH vaccination (days) }\end{array}$ \\
\hline Clumber spaniel & $436.3^{\text {cdef }}$ & $528.8^{\text {bcdef }}$ \\
Finnish hound & $369.9^{\mathrm{b}}$ & $400.6^{\mathrm{b}}$ \\
Italian greyhound & $291.5^{\mathrm{c}}$ & $355.6^{\mathrm{c}}$ \\
Pointer & $312.6^{\mathrm{d}}$ & $302.6^{\mathrm{d}}$ \\
Tibetan terrier & $214.9^{\mathrm{eb}}$ & $212.9^{\mathrm{ebc}}$ \\
West Highland white terrier & $259.8^{\mathrm{f}}$ & $310.2^{\mathrm{f}}$ \\
\hline
\end{tabular}

${ }^{1}$ Significant $(p<0.05)$ breed differences are indicated by the same superscript letters. 


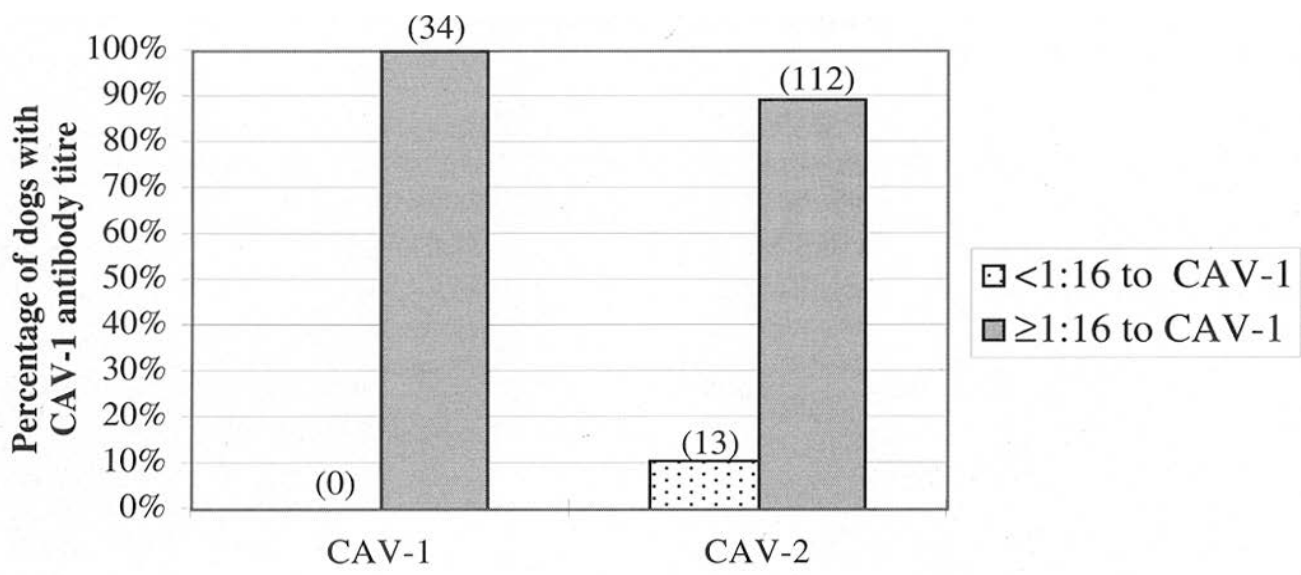

Vaccine type

Figure 4. Percentage of dogs with antibody titres $\geq 1: 16$ to CAV-1 and vaccinated with different types of vaccine.

or antibody levels $\geq 1: 16$ against CD or ICH whether last vaccination was performed $<1,1-2$ or $\geq 2$ years earlier.

There was a significant difference in the proportion of dogs reaching titres $\geq 1: 80$ against CPV between dogs not vaccinated and those vaccinated twice or more $(\mathrm{p}<0.001)$. There was also a significant increase in the fraction of dogs with $C D$ virus antibody levels $\geq 1: 16$ vaccinated twice or more $(\mathrm{p}<0.05)$. There was no statistical difference in the percentage of dogs with $\mathrm{ICH}$ virus antibody levels $\geq 1: 16$ among the groups vaccinated one, 2 or 3 times.

There was no statistical difference between vaccinated dogs less than one year of age and older dogs in the proportion reaching $\geq 1: 80$ against CPV, or $\geq 1: 16$ against $\mathrm{CD}$ or ICH.

\section{Discussion}

In Sweden, the disease situation regarding CPV, $\mathrm{CDV}$ and CAV-1 infections, as monitored by the Board of Agriculture, is good (Table 4), although there is some uncertainty regarding the true number of CPV infected dogs. Numbers of dogs infected with CDV and CAV-1 are very low, and all cases refer to young dogs that had not been vaccinated or had an incomplete vaccination history. Except for the dramatic numbers of CPV infections registered in the early 1980 's, the total numbers of dogs suffering from these 3 infectious diseases have been low in Sweden (Olson et al. 1988). The situation seems to be under control in most of the European countries (Grøndalen \& Sjerve 1994) although epidemiological information on infectious diseases in dogs, with the exception of rabies, are not well documented. There are, however, exceptions such as the distemper epidemics that have occurred recently in Finland (Liisa Sihvonen, personal communication, 1995), in Denmark (Blixenkrone-Möller et al. 1993) and in France (Adelus-Neveu et al. 1991). Not much has previously been published about the inclination of owners to vaccinate their dogs (Robertson et al. 1991). The most important finding from the questionnaire is that so many dogs have been vaccinated against CPV and 
Table 4. Total primary laboratory-verified incidences of infections with CPV, CDV and CAV-1 as reported to the Board of Agriculture 1986-1992.

\begin{tabular}{lrrrrrrrrrr}
\hline & \multicolumn{10}{c}{ Year } \\
\cline { 2 - 10 } Disease & 1986 & 1987 & 1988 & 1989 & 1990 & 1991 & 1992 & 1993 & 1994 & Total \\
\hline CPV infection & 153 & 79 & 68 & 28 & 24 & 34 & 11 & 9 & 7 & 413 \\
Canıne distemper & 1 & 1 & 3 & 6 & & 3 & 5 & & & 19 \\
Infectious canine hepatitis & 1 & 4 & 1 & & & & 3 & 6 & 4 & 19 \\
\hline
\end{tabular}

that almost every dog in Sweden has been vaccinated at least once against $\mathrm{CD}$ and $\mathrm{ICH}$. The figures on inclination to vaccinate dogs less than one year of age in the questionnaire are supported by the analysis on inclination to vaccinate in the antibody study. In a similar study from Australia, Robertson et al. (1991) reported that $90.8 \%$ of the dogs had been vaccinated at some time, with $72.7 \%$ vaccinated the preceding year. In a study on dogs from a Liverpool veterinary hospital population, $83 \%$ had been vaccinated against $\mathrm{CPV}$ and $\mathrm{CD}$ at least once, and of these animals $62 \%$ and $77 \%$ had been vaccinated as puppies against $\mathrm{CPV}$ and CD respectively (Tennant et al. 1991).

From the antibody study it is clear that a little more than $50 \%$ of all dogs are booster vaccinated between one to 2 years of age. This finding is also supported in the questionnaire. A booster vaccination at one year of age is a good practice to ensure that a dog is immunised in the absence of maternal antibodies.

The significant differences between owners of purebred dogs and owners of mixed breeds in their inclination to vaccinate, which was most pronounced for CPV vaccinations, could be explained by the fact that many of the mixedbreed dogs are not bred by experienced breeders, who have a strong influence on their puppy buyers on matters such as vaccinations. This is in accordance with the higher figures concerning inclination to vaccinate in the antibody study explained by the fact that this part of the study only contained purebred dogs.
A difference in vaccination pattern between breeds was found in the antibody study. For instance, Finnish hounds are considerably older when receiving their first $\mathrm{CPV}$ and $\mathrm{CD} / \mathrm{ICH}$ vaccination compared with all other breeds. The Finnish hound and Pointer are the only breeds among those selected that are used exclusively as gun dogs. The difference between the breeds in time since last vaccination is partly due to the difference in age within the material, Clumber spaniels being older.

A titre of 1:80 to CPV was chosen since it is generally accepted that this titre protects dogs against the disease (Pollock \& Carmichael 1982).

The overall numbers of vaccinated dogs reaching $\geq 1: 80$ in their CPV antibody titre in this study was $70.9 \%$ which is notably higher compared with the value obtained in the Swedish 1988 study (Olson et al. 1988). In 1988, the overall proportion of vaccinated dogs with an antibody $\geq 1: 80$ titre was below $40 \%$, and at no time after vaccination did this proportion exceed $50 \%$. The proportion of dogs with CPV titre $\geq 1: 80$ found in the current study is comparable to figures published from dogs in a Liverpool hospital population where $70 \%$ were positive at $\geq 1: 80$ (Tennant et al. 1991).

One reason for the higher proportion of vaccinated dogs with CPV antibody titres $\geq 1: 80$ in this study compared to the 1988 study, could be that a larger proportion of the puppies was vaccinated more than twice as a result of published recommendations on vaccinations (Olson et al. 1987). The proportions of dogs vaccinated 3 
times (48.3\%) and 4 times $(28.4 \%)$ against CPV before one year of age in this study were much higher than in the 1988 study $(13.1 \%$ and $2.4 \%$ respectively). It has earlier been shown that the chances of reaching protective levels can be improved by giving boosters of either killed or attenuated live CPV vaccines (O'Brien 1994, Olson et al. 1988, Wierup et al. 1982). In addition to this, introduction of attenuated live CPV vaccines on the Swedish market, and larger antigenic masses of the recent vaccines also contribute to the better results (Pollock \& Coyne 1993).

The interval between the most recent vaccination and the time of sampling may also have influenced on the result, being longer in the 1988 study than in the present one. In the study of Tennant et al. (1991), the presence of CPV antibodies was not influenced by factors such as age, vaccination status, or rural/urban living. This result was attributed to the continuous boosting of antibody levels through natural challenge, thus masking any vaccine-derived immunity (Tennant et al. 1991).

Although, the GMT titre did not differ significantly between groups, the proportion of dogs reaching $\geq 1: 80$ was significantly higher in the group receiving attenuated CPV vaccine at last vaccination than in the group vaccinated with killed vaccine. This is in accordance with other studies where attenuated vaccines have been proved to be more efficient than killed vaccines in eliciting antibody titres in the absence of maternally derived antibodies (Buonavoglia et al. 1992, Burtonboy et al. 1991, Pollock \&Coyne 1993).

A CDV/CAV-1 antibody level of $\geq 1: 16$ was chosen as protective level as the titre $\leq 1: 8$ in some samples was toxic to the cells and caused cell deaths in the virus neutralisation test. A titre of $\geq 1: 16$ could thereby certify that the dogs had a specific antibody titre to these viruses.

The overall frequency of vaccinated dogs with
CDV titers $\geq 1: 16$ in this study was $86.1 \%$, whereas it was only around $70 \%$ in 1988 (Olson et al. 1988). This discrepancy can be explained by the age difference between the 2 sets of dogs involved: in the present study only dogs younger than 5 years of age were selected whereas in the 1988 study dogs were selected at random. The corresponding figure in the Liverpool study was $84 \%$ (Tennant et al. 1991). There was no difference in the proportion of dogs with CDV titres $\geq 1: 16$ between vaccinated and non-vaccinated groups. In contrast, Tennant et al. (1991) showed that both the presence of and level of antibody to CDV were influenced by vaccination status. Our findings that $70 \%-80 \%$ of the dogs not documented as having been vaccinated against $\mathrm{CD} / \mathrm{ICH}$ showed elevated titres of the antibodies suggest that the current owners were in some cases mistaken; i.e. their dogs had in fact been vaccinated. It is doubtful that these dogs had been infected with wild virus since none of them had been ill. The risk that increased antibody titres were a reflection of a past subclinical infection rather than of vaccination induced immunity was probably low. This assumption is supported by official statistics as well as by the general impression that disease incidence is low. Consequently, the results of the comparison between vaccinated and non-vaccinated dogs should be interpreted with great caution.

The number of dogs with CAV- 1 titres $\geq 1: 16$ was $91.6 \%$ in this study but only about $80 \%$ in the 1988 study. This difference is also reflected in the overall GMT which was 1:84 and 1:37 respectively. In the 1988 study it was not possible to compare dogs vaccinated with killed CAV-1 vaccine with those vaccinated with attenuated live CAV-1 vaccine. In the present study, however, significant differences were found between these 2 categories in the number of dogs with titre $\geq 1: 16$ and in GMT. A possible explanation for this could be that vaccination 
with the modified live CAV-2 virus vaccine results in lower concentration of heterotypic (CAV-1) antibody compared with the use of killed CAV-1 vaccines (Fischerman \& Scarnell 1976).

The dogs in the antibody study could either have been vaccinated with a signal component vaccine or with a combination of one to 3 different vaccines at the same time. The combinations could have been a mix of attenuated live and inactivated vaccines. This study has not evaluated the possible interactions between the different vaccine components. There are reports in the literature on immunomodulative effects when using combination vaccines (Phillips et al. 1989, Miyamoto et al. 1992, Miyamoto et al. 1995), although without affecting the antibody titre levels (Phillips et al. 1989).

A high inclination to vaccinate and the availability of effective vaccines are important prerequisites for keeping a population free from disease caused by CPV, CDV or CAV-1. The most significant findings of this study are that there was a high overall inclination to vaccinate. The highest inclination to vaccinate was found in owners of purebreds $(90 \%)$, except for some breed of gun dogs, whereas the corresponding value for owners of mixed breed dogs was $10-20 \%$ lower. A higher proportion of the Swedish dog population was found to be protected against CPV when compared to the situation in 1988. The variation in the capacity of the different vaccines to elicit an antibody response is also an important finding. Live attenuated CPV vaccines and boostring increased the fraction of dogs protected against CPV. In contrast, the inactivated CAV- 1 vaccine was superior to attenuated CAV-2 vaccines in evoking immunity.

\section{Acknowledgements}

This study was supported by grants from the Swedish Kennel club and Agria Insurance. The support from Masterfood ab is greatly appreciated.

\section{References}

Adelus-Neveu F, Saint-Gerand AL, Fayet G, Wiedemann C: Hundestaupe: Lehren aus einer Epizootie in Frankreich. (Canıne Distemper: Experience from an epizootic in France). Praktısche Tierartzt. 1991, 72, 869-871.

Appel M, Robson D: A microneutralization test for canine distemper. Amer. J vet. Res. 1973, 34, 1459-1463.

Blixenkrone-Möller M, Svansson V, Have P, Orvell C, Appel M, Pedersen IR, Dietz HH, Henriksen P: Studies on manifestations of canine distemper v1rus infection in an urban dog population. Vet. microbiol. 1993, 37, 163-173.

Buonavoglia C, Tollis M, Buonavoglia D, Puccine A: Response of pups with maternal derived antibody to modified-live canıne parovovirus vaccine. Comp. Immun. Microbiol. infect. Dis. 1992, 15, 281-283.

Burtonboy S, Charlier P, Hertoghs J, Lobmann M, Wiseman $A$, Woods $S \cdot$ Performance of a high titre attenuated canıne parvovirus vaccine in pups with maternally derived antibody. Vet. Rec. 1991, 129, 377-381.

Fischerman B, Scarnell J. Persistence of protection after vaccination against infectıous canine hepatitis vırus (CAV/1). Vet. Rec. 1976, 99, 599.

Grøndalen J, Sjerve E: Infectious disesases among dogs and cats in Europe. The European $J$ of Comp. Animal Pract. 1994, 4, 16-19.

Miyamoto T, Taura Y, Une S, Yoshitake M, Nakama S, Watanbe $S$ : Changes in blastogenetic response of lymphocytes and delayed type hypersensitivity responses after vaccination in dogs. $\mathrm{J}$ vet. Med. Sci. 1992, 54, 945-950.

Miyamoto T, Taura Y, Une S, Yoshitake M, Nakama S, Watanbe $S$ : Immunlogical response to polyvalent canine vaccines in dogs: J vet. Med. Sci. 1995, 57, 347-349.

O'Brien SE: Serologic response of pups to the lowpassage, modified live canine parvovirus-2 component in a combination vaccine. $\mathrm{J}$ Amer. vet. med. Ass. 1994, 204, 1207-1209.

Olson P, Hedhammar A, Klingeborn B. Nya rekommendationer för vaccination av hund. (New recommendations for vaccination of dogs). Svensk Veterinärtıdning. 1987, 39, 829-831.

Olson P, Klingeborn B, Hedhammar A: Serum antibody response to canine parvovirus, canıne adenovirtus-1, and canine distemper virus in dogs with known status of immunization: Study of 
dogs in Sweden. Amer. J vet. Res. 1988, 49, 1460-1644.

Phillips TR, Jensen JL, Rubino MJ, Yang WC, Shultz $R D$ : Effects of vaccines on the canine immune system. Can. J Vet. Res. 1989, 53, 154-160.

Pollock RVH, Carmichael LE: Dog response to inactivated canıne parvovirus and felıne panleukopenaia virus vaccines. Cornell Vet 1982, 72, 16-35.

Pollock RVH, Coyne MJ Canıne Parvovirus. Vet. Clininics N Am. Small Anımal. 1993, 23, 555568.

Rimmelzwaan GF, Junttı N, Klıngeborn B, Groen J, UytdeHaag FGCM, Osterhaus ADME: Evaluation of enzymelınked immunoabsorbent assays based on monoclonal antıbodies for the serology and antigen detection in canine parvovirus infections. Vet. Quartly. 1990, 12, 14-20.

Robertson ID, Shaw SE, Clark WT: The use of health management practices by a randomly selected group of dog owners in Perth. Austr. vet. Pract1. 1991, 21, 126-130.

Tennant BJ, Gaskell RM, Jones RC, Gaskell CJ: Prevalence of antıbodies to 4 major canıne viral diseases in dogs in a Liverpool hospital population. J Small Animal Pract. 1991, 32, 175-179.

Wierup $M$, Olson P, Hedhammar $A$, Klingeborn $B$, Karlsson $K-A \cdot$ Evaluation of a killed feline panleukopenıa virus vaccine against canıne parvoviral enteritıs in dogs. Amer. J vet. Res. 1982, 43, 2183-2187.

\author{
Sammanfattning \\ Parvovirusinfektion, valpsjuka och HCC - Benägen- \\ het att vaccinera och antikroppssvar hos den svenska \\ hundpopulatıonen.
}

Djurägares benägenhet att vaccinera sina hundar undersöktes hos slumpvis utvalda hundägande svenska hushåll. Enligt ägarna $(n=538)$ hade $87,7 \%$ av hundarna blivit vaccinerade någon gång mot $\mathrm{CPV}$ (canine parvo virus) och $95,8 \%$ hade blivit vaccinerade mot CD/ICH (canıne distemper/infectious canıne hepatttis). Benägenheten att vaccinera blandrashundar var sıgnifikant lägre jämfört med rasrena hundar. I en andra del av studien analyserades antikroppshalten mot CPV CD och CAV-1 hos 176 slumpvis utvalda hundar med känd vaccınationsbakgrund. CPV ant1kroppshalter $\geq 1: 80$ uppmättes hos $70,9 \%$ av de vaccinerade hundarna. Andelen hundar som nådde $\geq 1: 80$ 1 titer mot CPV var signifikant högre $i$ den grupp som var vaccinerade med levande modifierat parvovirusvaccın jämfört med hundar vaccınerade med avdödat vaccın. Antıkroppstitrar mot CD och CAV-1 $\geq 1: 16$ uppmättes hos $86,1 \%$ och $91,6 \%$ respektive. Andelen hundar med CAV-1 antıkroppar $\geq 1$ :16 var signifikant högre 1 den grupp hundar som vaccınerats med inaktıverat $C A V-1$ vaccın jämfört med den grupp som vaccinerats med modifierat levande CAV-2 vaccın. Ungefär $50 \%$ av hundarna booster vaccinerades mot alla tre sjukdomarna vid cirka ett års ålder.

(Received February 23, 1996; accepted August 19, 1996)

Reprints may be obtained from: P. Olson, Department of Medicine and Surgery, Swedısh Unıversity of Agnicultural Sciences, Box 7037, S-75007 Uppsala, Sweden. 
